\title{
PEMBELAJARAN MODEL KOOPERATIF TIPE GROUP INVESTIGATION UNTUK MENINGKATKAN HASIL BELAJAR FISIKA PADA SISWA KELAS X SMA NEGERI 10 BULUKUMBA
}

\author{
Hasisba Isnayanto ${ }^{1}$ \\ SMA Negeri 10 Bulukumba \\ Email : hasishayyong@gmail.com
}

\begin{abstract}
ABSTRAK
Penelitian ini bermaksud untuk mengetahui tingkat keaktifan peserta didik selama proses pembelajaran dengan model pembelajaran kooperatif tipe Group Investigation (GI), Untuk mengetahui peningkatan hasil belajar peseta didik dengan penerapan model pembelajaran kooperatif tipe Group Investigation (GI) dan untuk mengetahui aktivitas pendidik selama proses pembelajaran melalui penerapan model pembelajaran kooperatif tipe Group Investigation (GI). Penelitian ini merupakan penelitian tindakkan kelas (classroom action research). Penelitian ini terdiri atas serangkaian siklus, setiap siklus meliputi empat tahap yaitu : perencanaan, pelaksanaan tindakan, observasi dan refleksi. Subjek dalam penelitian ini adalah siswa kelas $X_{1}$ SMA Negeri 10 Bulukumba tahun pelajaran 2017/2018 semister genap yang berjumlah sebanyak 35 siswa, terdiri dari 13 siswa laki-laki dan 22 siswa perempuan. Adapun Instrumen yang digunakan dalam penelitian ini adalah Lembar observasi dan test. Teknik analisis data yang digunakan dalam penelitian ini menggunakan analisis data deskriptif kualitatif. Analisis data kualitatif digunakan untuk mengolah data hasil observasi guru dan siswa. Adapun teknik data deskriptif kualitatif digunakan untuk menghitung presentase nilai rata - rata. Kriteria Ketuntasan Minimal (KKM) yang diterapkan pada mata pelajaran Fisika adalah 75. Jadi nilai siswa dapat dikatakan tuntas apabila mencapai nilai KKM (Kriteria Ketuntasan Minimal). Berdasarkan hasil analisis dan pembahasan dalam penelitian tindakan dapat disimpulkan bahwa melalui pembelajaran kooperatif tipe Group Investigation dapat meningkatkan hasil belajar peserta didik pada mata pelajaran Fisika standar kompetensi memahami konsumsi dan investasi di kelas $X_{I}$ SMA Negeri 10 Bulukumba kabupaten Luwu. Hal ini dapat dilihat dari hasil observasi dan hasil tes belajar peserta didik, dimana dari hasil observasi tersebut terdapat pengembangan baik dari segi kehadiran serta keaktifan dan dari hasil tes peserta didik terdapat peningkatan dimana hasil tes siklus I peserta didik yang tuntas sebanyak 66,00 persen, sedangkan peserta didik yang tuntas pada tes siklus II sebanyak 83,00 persen
\end{abstract}

Kata kunci: Pembelajaran Kooperatif, Group Investigation, Hasil Belajar, Fisika

\section{PENDAHULUAN}

Pendidikan memiliki peranan yang sangat penting, yaitu merupakan proses pembentukan kepribadian dan kecakapan peserta didik yang bertujuan untuk membantu peserta didik dapat mengembangkan potensi, pengetahuan dan keterampilannya. Dalam tingkatan praksis, tujuan pendidikan yang dikemukakan oleh
Tirtarahardja dkk (2010:38) "memuat gambaran tetang nilai-nilai yang baik, luhur, pantas, benar, dan indah untuk kehidupan". Karena itu tujuan pendidikan memiliki dua fungsi yaitu memberikan arah kepada segenap kegiatan pendidikan dan merupakan sesuatu yang ingin dicapai oleh segenap kegiatan pendidikan.

Dalam rangka mencapai tujuan pendidikan maupun tujuan belajar itu sendiri 
kurikulum dan proses pembelajaran sebagai salah satu faktor pendukungOleh karena itu perubahan kurikulum dari kurikulum 2013 ke KTSP menjadi salah satu faktor penunjang keberhasilan peserta didik, adapun Peraturan Mentri Pendidikan dan Kebudayaan Republik Indonesia No 160 Tahun 2014 Tentang Pemberlakuan Kurikulum 2006 dan Kurikulum 2013 Pasal 1 menyatakan bahwa Satuan pendidikan dasar dan pendidikan menengah yang melaksanakan kurikulum 2013 sejak semester pertama tahun pelajaran 2014/2015 kembali melaksanakan kurikulum tahun 2006 mulai semester kedua tahun pelajaran 2014/2015 sampai ada ketetapan dari kementrian untuk melaksanakan kurikulum 2013.

Dalam penyelenggaraan pendidikan banyak komponen yang membentuk sebuah kesuksesan Pendidikan dan salah satu komponen yang sangat penting yaitu Pendidik dan Peserta Didik. Pendidik dan Peserta Didik saling berinteraksi sehingga diwujudkan adanya interaksi pembelajaran atau proses pembelajaran yang dilakukan antara Pendidik dan Peserta Didik. Penyelenggaraan ini Pendidik merencanakan proses pembelajaran yang sistematis yang sesuai dengan standar proses pendidikan. Berdasarkan Peraturan Pemerintah No.32 Tahun 2013 Pasal 1 Ayat 1 mengemukakan "Standar Nasional Pendidikan adalah kriteria minimal tentang sistem pendidikan diseluruh wilayah hukum Negara Republik Indonesia".

Berdasarkan pada Peraturan Pemerintah No. 32 Tahun 2013 Pasal 1 ayat 19 tentang standar nasional pendidikan bahwa: Pembelajaran adalah "proses interaksi antar peserta didik, antara peserta didik dengan pendidik dan sumber belajar pada suatu lingkungan belajar".

Sejalan dengan hal tersebut Hamalik (2011:57) mengemukakan bahwa "Pembelajaran adalah suatu kombinasi yang tersusun meliputi unsur-unsur manusiawi, material, fasilitas, perlengkapan dan prosedur yang saling mempengaruhi untuk mencapai tujuan pembelajaran". Manusia terlibat dalam sistem pengajaran yang terdiri dari Peserta Didik, Pendidik, dan tenaga lainnya, misalnya tenaga laboratoriun. Material meliputi buku-buku, papan tulis dan kapur, fotografi, slide dan film, audio dan video tape. Fasilitas dan perlengkapan, terdiri dari ruang kelas, perlengkapan audio visual, dan juga komputer. Prosedur, meliputi jadwal dan metode, penyampain informasi, praktek, belajar, ujian dan sebagainya. Dengan terpenuhinya semua unsur-unsur seperti Pendidik yang berkulitas, buku-buku yang lengkap, metode yang digunakan pada saat pembelajaran tepat, cara penyampaian materinya kreatif sehinggga peserta didik cepat memahaminya maka tujuan pembelajaran besar kemungkinan dapat dicapai.

Menurut Hamalik (2011:76) "Dalam rangka menentukan tujuan pembelajaran adalah kebutuhan Peserta Didik, mata ajaran dan Pendidik itu sendiri". Berdasarkan kebutuhan Peserta Didik dapat ditetapkan apa yang hendak dicapai dan dikembangkan dan diapresiasi. Berdasarkan mata ajaran yang ada dalam petunjuk kurikulum dapat ditentukan hasil-hasil pendidikan yang diinginkan. Pendidik sendiri adalah sumber utama tujuan bagi para Peserta Didik dan dia harus mampu menulis dan memilih tujuantujuan pendidikan yang bermakna, dan dapat terukur dan bermamfaat bagi peserta didik.

Tujuan pembelajaran dapat tercapai manakalah dalam proses pembelajaranya berjalan dengan lancar. Proses pembelajaran akan lancar jika unsur-unsut yang berkaitan dalam proses pembelajaran saling mendukung salah satunya model pembelajaran yang digunakan pendidik dalam mengajar. Namun Saat ini banyak kita lihat pendidik sering kali menggunakan model pembelajaran yang tidak relevan dengan materi yang diajarkan, dan kadang kala pendidik belum profesional dalam menggunakan model pembelajaran akibatnya banyak peserta didik yang tidak 
memperhatikan peroses pembelajaran. Pada akhirnya mempengaruhi hasil belajar peserta didik, tujuan pembelajaran tidak tercapai dan kualitas output sekolah akan rendah.

Permasalah pembelajaran yang diungkap tersebut terjadi pada peserta didik di SMA Negeri 10 Bulukumba. Permasalahan ini paling serius terjadi di Kelas X yang keadaan kelasnya pada saat proses pembelajaran kurang aktif, suasana kelas kurang kondusif saat proses pembelajaran berlangsung. Model pembelajaran yang digunakan terutama pada mata pelajaran ekomoni tidak menarik minat belajar peserta didik. Sehingga prestasi belajar peserta didik sangat rendah dan berpengaruh pada hasil belajar peserta didik.

Melihat permasalah yang terjadi disekolah tersebut maka peneliti berinisiatif menerapkan Model Pembelajaran kooperatif Tipe Group investigation dalam meningkatkan hasil belajar peserta didik pada mata pelajaran Fisika Kelas X IPA 1 SMA Negeri 10 Bulukumba.

Salah Satu pertimbangan mengambil model pembelajaran kooperatif Tipe Group Investigation dalam penelitian ini karna melihat penelitian terdahulu yang menggunakan model pembelajaran Tipe kooperatif Group Investigation dalam penelitiannya dapat meningkatkan hasil belajar peserta didik. Salah satu penelitian terdahulu yang menggunakan model pembelajaran kooperatif Tipe Group Investigation yaitu: Menurut A. Firmansyah (2012) dalam penelitiannya model Pembelajaran kooperatif Tipe Group Investigation dapat meningkatkan hasil belajar sosiologi sub pokok bahasan strativikasi sosial pada siswa kelas XI SMA Negeri 1 Kajuara Kabupaten Bone. Terbukti dengan melihat hasil penelitiannya, Peningkatan hasil belajar siswa dapat dilihat dari hasil tes evaluasi siklus I dan siklus II yang kemudian dianalisis. Berdasarkan hasil analisis data dan pembahasan diperoleh nilai rata-rata pada siklus I sebesar 57,95 dengan presentase ketuntasan hanya sebesar 92,85 persen sedangkan nilai rata-rata siklus II meningkat menjadi 77,30 dengan presentase ketuntasan 77,14 persen .hasil uji hipotesis diperoleh peningkatan dari siklus I ke siklus II itu menunjukkan bahwa dengan penerapan pembelajaran kooperatif tipe Group Investigation (GI) dapat meningkatan hasil belajar sosiologi siswa kelas XI SMA Negeri 1 Kajuara Kabupaten Bone.

Melihat hasil penelitian terdahulu di atas memperkuat alasan memilih model pembelajaran kooperatif Tipe Group Inverstigation dalam penelitian ini. Group Investigation (GI) merupakan salah satu tipe pembelajaran kooperatif yang dikembangkan oleh Sholomo Sharan dan Yael Sharan di Universitas Tel Aviv, Israel. Pada model pembelajaran kooperatif tipe Group Investigation (GI) ini melibakan siswa sejak perencanaan baik dalam seleksi topik siswa diberi kesempatan untuk berkomunikasi, bekerja sama dan berinteraksi sosial dengan temannya untuk mempelajarinya melalui investigasi. Dengan model pembelajaran ini siswa dilatih bagaimana mengutarakan pendapat dan siswa juga belajar menghargai pendapat orang lain dengan tetap mengacu pada materi/tujuan pembelajaran, sementara guru bertindak sebagai motivator dan fasilitator aktivitas siswa. Dengan menggunakan model pembelajaran kooperatif tipe Group Investigation (GI) ini diharapkan dapat mencapai tujuan pembelajaran yang diharapkan.

\section{KAJIAN PUSTAKA}

\section{Pengertian Belajar dan Pembelajaran}

Belajar pada hakikatnya adalah proses interaksi terhadap semua sisuasi yang ada disekitar individu. Belajar dapat dipandang sebagai proses yang diarahkan kepada tujuan dan proses berbuat melalui berbagsi pengalaman. Dalam proses pengajaran, unsur proses belajar memegang peranan yang vital. Bahwa mengajar adalah proses membimbing kegiatan belajar, dan bahwa kegiatan mengajar hanya bermakna apabila terjadi kegiatan belajar siswa. Oleh karena itu, 
adalah penting sekali bagi setiap guru memahami sebaik-baiknya tentang proses belajar siswa, agar ia dapat memberikan bimbingan dan menyediakan lingkungan belajar yang tepat dan serasi bagi siswa. Sampai saat ini, hampir ahli telah mencoba merumuskan dan membuat tafsiran tentang belajar. Seringkali pula perumusan dan tafsiran itu berbeda satu sama lain. Berikut ini beberapa perumusan tentang belajar guna melengkapi dan memperluas pandangan tentang belajar.

Menurut Hilgard dalam Sanjaya (2006:112) megemukajkan bahwa Belajar adalah proses perubahan melalui kegiatan atau prosedur latihan baik latihan di dalam laboratorium maupun dalam lingkungan alamiah. Belajar bukanlah sekedar mengumpulkan pengetahuan. Belajar adalah proses mental yang terjadi dalam diri seseorang sehingga menyebabkan munculnya perubahan perilaku.

Menurut Slameto dalam Haling (2007:1) bahwa: belajar ialah "suatu proses yang dilakukan seseorang untuk memperoleh suatu perubahan tingkah laku yang baru secara keseluruhan, sebagai hasil pengalamannya sendiri dalam interaksi dengan lingkungannya".

Menurut Sahabuddin dalam Haling (2007:2) mengemukakan bahwa belajar "ialah sebagai suatu proses kegiatan yang menimbulkan kelakuan baru atau merubah kelakuan lama sehingga seseorang lebih mampu memecahkan masalah dan menyesuaikan diri terhadap situasi-situasi yang dihadapi dalam hidupnya".

Menurut Hamalik dalam Haling (2007:2) bahwa: belajar adalah "suatu perkembangan dari seseorang yang dinyatakan dalam cara bertingkah laku yang baru berkat pengalaman dan latihan".

Dari beberapa pendapat di atas dapat dijelaskan bahwa belajar merupakan kegiatan penting yang harus dilakukan setiap orang secara maksimal untuk dapat menguasai atau memperoleh sesuatu. Belajar adalah kegiatan yang dilakukan seseorang dalam rangka mengubah tingkah laku kearah yang lebih baik sesuai dengan apa yang diharapkan. Sebagian besar dari proses perkembangan berlangsung melalui kegiatan belajar. Sehingga untuk belajar, seorang pelajar tidak dapat terlepas dari orang lain, dalam hal ini guru dan teman belajar. Dengan demikian guru sebagai fasilitator serta pembimbing dan teman belajar sebagai teman diskusi.

Dalam proses pendidikan disekolah guru mempunyai peran untuk membimbing dan mengajar, sedangkan siswa bertugas untuk belajar.Dengan adanya interaksi tersebut antara belajar dan mengajar maka timbullah proses pembelajaran.

Menurut Degeng dan Miarso dalam Haling (2007:14) bahwa Pembelajaran adalah suatu proses yang dilaksanakan secara sistematik di mana setiap komponen saling berpengaruh, dalam proses secara implisit terdapat kegiatan memilih menetapkan dan mengembangkan metode untuk mencapai hasil pembelajaran yang diinginkan. Pembelajaran menaruh perhatian pada bagaimana membelajarkan pembelajaran dan lebih menekankan pada cara mencapai tujuan. Sanjaya (2008:26) mengemukakan bahwa pembelajaran dapat diartikan sebagai proses kerja sama antara guru dan siswa dalam memanfaatkan segala potensi dan sumber yang ada baik potensi yang bersumber dari dalam diri siswa itu sendiri seperti minat, bakat, kemampuan dasar yang dimiliki termasuk gaya belajar maupun potensi yang ada diluar diri siswa, seperti lingkungan, sarana dan sumber belajar sebagai upaya untuk mencapai tujuan belajar tertentu.

Berdasarkan pendapat di atas maka pembelajaran merupakan suatu kombinasi yang kompleks antara guru dengan siswa, fasilitas, dan prosedur yang saling mempengaruhi sehingga mencapai tujuan.

\section{Model Pembelajaran Kooperatif}

Pembelajaran kooperatif merupakan suatu pembelajaran kelompok dengan jumlah 
peserta didik 2-5 orang dengan gagasan untuk saling memotivasi antara anggotanya untuk saling membantu agar tercapainya suatu tujuan pembelajaran yang maksimal. Berikut ini merupakan beberapa pengertian pembelajaran kooperatif (cooperative learning) menurut para ahli.

$\begin{array}{llr}\begin{array}{l}\text { Johnson } \\ \text { (2012:204) }\end{array} & \text { Hasan dalam } & \text { Rusman } \\ \text { Cooperative } & \text { Learning adalah } & \text { teknik }\end{array}$
pengelompokan yang didalamnya siswa bekerja terarah pada tujuan belajar bersama dalam kelompok kecil yang umumnya terdiri dari 4-5 orsng. Belajar cooperative adalah pemamfaatan kelompok kecil dalam pembelajaran yang memungkinkan siswa bekerja anggota sama untuk memaksimalkan bekerja mereka dan bekerja anggota lainnya dalam kelompok tersebut.

Nurhayati dalam Rusman (2012:203) "pembelajaran kooperatif adalah strategi pembelajaran yang melibatkan partisipasi siwa dalam satu kelompok kecil untuk saling berinteraksi".

Tom V. Savage dalam Rusman (2012:203) "mengemukakan bahwa cooperative learning adalah suatu pendekatan yang menekankan kerja sama dalam kelompok".

Rusman (2012:205) “model pembelajaran kooperatif merupakan mpdel pembelajaran yang banyak digunakan dan menjadi perhatian serta dianjurkan oleh para ahli pendidikan".

Bersadarkan uraian di atas mengenai pembelajaran kooperatif dapat disimpulkan bahwa pembelajaran kooperatif diharapkan mampu meningkatkan kualitas pembelajaran. Dan dalam model pembelajaran kooperatif ini guru berpesan sebagai fasilitator yang berfungsi sebagai jembatan penghubung kearah pemahaman yang lebih tinggi, dengan catatan peserta didik sendiri. Guru tidak hanya memberikan pengetahuan akan tetapi mengembangkan untuk menerapkan ide-ide mereka sendiri. Namun peserta didik tidak

Fakultas Keguruan dan Ilmu Pendidikan Universitas Bosowa Makassar hanya belajar dari guru akan tetapi juga belajar dari teman.

Strategi pembelajaran kooperatif merupakan serangkaian kegiatan pembelajaran yang dilakukan oleh siswa didalam kelompok, untuk mencapai tujuan pembelajaran yang telah ditetapkan. Menurut Rusman (2012:204) terdapat empat hal penting dalam strategi pembelajaran kooperatif yaitu :

a. Adanya peserta didik dalam kelompok

b. Adanya aturan main (role) dalam kelompok

c. Adanya upaya belajar dalam kelompok

d. Adanya kompotensi yang harus dicapai oleh kelompok

Nurulhayati dalam Rusman (2012:204), mengemukakan 5 unsur dasar model cooperative learning, yaitu:

a. Ketergantungan yang positif,

b. Pertanggungjawaban individual,

c. Kemampuan bersosialisasi,

d. Tatap muka dan

e. Evaluasi proses kelompok.

Berdasarkan uraian di atas dapat disimpulkam bahwa pembelajaran kooperatif mewadahi bagaimana siswa bekerja sama dalam kelompoknya, siswa harus merasakan bahwa mereka akan mencapai tujuan, maka siswa lain dalam kelompoknya memiliki kebersamaan, artinya tiap anggota kelompok bersikap kooperatif dengan sesama anggota kelompoknya.

\section{Metode Pembelajaran Kooperatif Tipe Group Ivestigation (GI)}

Dasar-dasar Group Investigation(GI) dirancang oleh Herbert Thelen, selanjutnya diperluas dan diperbaiki oleh Shan dan teman-temannya dari Universitas Tel Aviv. Group Invertigation (GI) melibatkan siswa sejak perencanaan, baik dalam seleksi topik maupun cara untuk mempelajarinya melalui investigasi. Metode ini menuntut siswa untuk memiliki kemampuan yang baik dalam berkomunikasi maupun dalam keterampilan 
proses kelompok (group process skills). Dalam menggunakan group invertigation umumnya kelas dibagi menjadi beberapa kelompok dengan anggota 5 sampai 6 orang siswa dengan karakteristik yang heterogen. Pembagian kelompok dapat juga di dasarkan atas kesenangan berteman atau kesamaan minat terhadap suatu topik tertentu. Para siswa memilih topik yang ingin dipelajari, mengikuti investigasi mendalam terhadap berbagai sub topik yang telah dipilih, kemudian menyiapkan dan menyajikan suatu laporan di depan kelas secara keseluruhan.

Aqib (2014 :26) mengemukakan bahwa tipe Group Investigation memiliki langkahlangkah sebagai berikut :

a. Guru membagi siswa dalam beberapa kelompok heterogen.

b. Guru menjelaskan maksud pembelajaran dan tugas ke kelompok.

c. Guru memanggil ketua-ketua untuk satu materi tugas sehingga satu kelompok mendapat tugas satu materi/tugas yang berbeda dari kelompok lain.

d. Masing-masing kelompok membahas materi yang sudah ada secara kooperatif berisi penemuan.

e. Setelah selesai diskusi, lewat juru bicara, ketua menyampaikan hasil pembahasan kelompok.

f. Guru member penjelasan singkat sekaligus member kesimpulan.

g. Evaluasi

h. Penutup.

Setiap model pembelajaran pasti akan ada kelebihan dan kekurangan yang dimiliki, setiap model pembelajaran pasti memiliki kelebihan dan kekurangan yang berbedabeda. Menurut Sumarmi (2012) diakses mengemukakan bahwa kelebihan dan kekurangan pembelajaran kooperatif tipe Group Investigation yaitu:

a. Kelebihan model pembelajaran tipe Group Ivestigation
1) Siswa yang berpartisipasi dalam GI cenderung berdiskusi dan menyumbangkan ide tertentu.

2) Gaya bicara dan kerjasama siswa dapat diobservasi.

3) Siswa dapat belajar kooperatif lebih efektif, dengan demikian dapat meningkatkan interaksi sosial mereka.

4) GI dapat mendorong siswa untuk berpartisipasi aktif, sehingga pengetahuan yang diperoleh dapat ditransfer ke situasi diluar kelas.

5) GI mengijinkan guru untuk lebih informal.

6) GI dapat meningkatkan penampilan dan prestasi belajar siswa

b. Kekurangan Model pembelajaran tipe Group Investigation

1) GI tidak ditunjang oleh adanya hasil penelitian yang khusus.

2) Proyek-proyek kelompok sering melibatkan siswa-siswa yang mampu.

3) Keberhasilan model GI bergantung pada kemampuan siswa memimpin kelompok atau bekerja mandiri.

Group Investigation merupakan salah satu bentuk tipe model pembelajaran kooperatif yang menekankan pada partisipasi dan aktivitas siswa untuk mencari sendiri materi (informasi) pelajaran yang akan dipelajari melalui bahan-bahan yang tersedia, misalnya dari buku pelajaran atau siswa dapat mencari melalui internet. Siswa dilibatkan sejak perencanaan, baik dalam menentukan topik maupun cara untuk mempelajarinya melalui investigasi. Tipe ini menuntut para siswa untuk memiliki kemampuan yang baik dalam berkomunikasi maupun dalam keterampilan proses kelompok. Model pembelajaran kooperatif tipe Group Investigation dapat melatih siswa untuk menumbuhkan kemampuan berfikir mandiri. Keterlibatan siswa secara aktif dapat terlihat mulai dari tahap pertama sampai tahap akhir pembelajaran. 


\section{Hasil Belajar}

Belajar dan mengajar merupakan konsep yang tidak dapat dipisahkan. Belajar merujuk pada apa yang harus dilakukan seseorang sebagai subyek dalam belajar. Sedangkan mengajar merujuk pada apa yang seharusnya dilakukan seseorang guru sebagai pengajar.

Keputusan tentang hasil belajar merupakan umpan balik bagi siswa dan bagi guru. Keputusan hasil belajar merupakan puncak didik.Secara kejiwaan, pesta didik terpengaruh atau tercekam dengan hasil belajarnya. Oleh karena itu, sekolah dan guru diminta berlaku arif serta bijak dalam menyampaikan keputusan hasil belajar siswa, sehingga siswa mempunyai motivasi dalam kegiatan pembelajaran untuk mencapai hasil belajar yang maksimal.

Dua konsep belajar mengajar yang dilakukan oleh siswa dan guru terpadu dalam satu kegiatan. Diantara keduannya itu terjadi interaksi dengan guru. Kemampuan yang dimiliki siswa dari proses belajar mengajar saja harus bisa mendapatkan hasil bisa juga melalui kreatifitas seseorang itu tanpa adanya intervensi orang lain sebagai pengajar. Oleh karena itu hasil belajar yang dimaksud disini adalah kemampuan-kemampuan yang dimiliki seorang siswa setelah ia menerima perlakukan dari pengajar (guru).

Menurut Gagne dalam Dimyati (2006:9) berpendapat bahwa "belajar merupakan kegiatan yang kompleks, setelah belajar orang memiliki keterampilan, pengetahuan, sikap, dan nilai".

Gagne dalam Sanjaya (2008: 163), mengidentifikasi lima jenis hasil belajar, yaitu:

a. Belajar keterampilan intelektual yakni belajar diskriminasi, belajar konsep, dan belajar kaidah.

b. Belajar informasi verbal, yaitu belajar melalui simbol-simbol tertentu.

c. Belajar mengatur kegiatan intelektual, yakni belajar mengatur kegiatan intelektual yang berhubungan dengan kemampuan mengaplikasikan keterlampilan intelektual.Belajar sikap, yaitu belajar menentukan tindakan tertentu.

d. Belajar keterampilan motorik, yaitu belajar melakukan gerakan-gerakan tertentu mulai dari yang sangat sederhana hingga yang kompleks seperti mengoperasikan mesin atau kendaraan.

Berkaitan dengan jenis-jenis hasil belajar tersebut, dapat dikemukakan bahwa hasil belajar siswa merupakan perubahan tingkah laku siswa yang mencakup aspek kognitif, afektif, dan psikomotorik.

\section{Hubungan model pembelajaran Group Investigation dengan hasil belajar}

Group Investigation merupakan salah satu bentuk tipe model pembelajaran kooperatif yang menekankan pada partisipasi dan aktivitas siswa,Tipe ini menuntut para siswa untuk memiliki kemampuan yang baik dalam berkomunikasi maupun dalam keterampilan proses kelompok. Model pembelajaran kooperatif tipe Group Investigation dapat melatih siswa untuk menumbuhkan kemampuan berfikir mandiri. Keterlibatan siswa secara aktif dapat terlihat mulai dari tahap pertama sampai tahap akhir pembelajaran.

Menurut Dimyati dkk (2006:3-4) mengemukakan bahwa Hasil belajar merupakan hasil dari suatu interaksi tindak belajar dan tindak mengajar. Dalam hal ini adalah dua konsep belajar mengajar yang dilakukan oleh siswa (tindak belajar) dan guru (tindak mengajar) terpadu dalam satu kegiatan. Diantara keduannya terjadi interaksi sehingga siswa mendapatkan hasil belajar dari proses kegiatan tersebut .

Dengan melihat penjelasan diatas maka jelas bahwa hubungan Group Investigation dengan Hasil Belajar sangatlah erat kaitannya. Dengan penerapan model pembelajaran tipe Group Investigation ini dapat meningkatkan kemampuan berpikir atau keterampilan sehingga meningkatkan hasil belajar peserta didik. 


\section{METODE PENELITIAN}

Penelitian ini merupakan penelitian tindakkan kelas (classroom action research). Penelitian ini terdiri atas serangkaian siklus, setiap siklus meliputi empat tahap yaitu : perencanaan, pelaksanaan tindakan, observasi dan refleksi. Subjek dalam penelitian ini adalah siswa kelas $\mathrm{X}_{1}$ SMA Negeri 10 Bulukumba tahun pelajaran 2017/2018 semister genap yang berjumlah sebanyak 35 siswa, terdiri dari 13 siswa lakilaki dan 22 siswa perempuan. Adapun Instrumen yang digunakan dalam penelitian ini adalah Lembar observasi dan test. Teknik analisis data yang digunakan dalam penelitian ini menggunakan analisis data deskriptif kualitatif. Analisis data kualitatif digunakan untuk mengolah data hasil observasi guru dan siswa. Adapun teknik data deskriptif kualitatif digunakan untuk menghitung presentase nilai rata - rata. Kriteria Ketuntasan Minimal (KKM) yang diterapkan pada mata pelajaran Fisika adalah 75. Jadi nilai siswa dapat dikatakan tuntas apabila mencapai nilai KKM (Kriteria Ketuntasan Minimal).

\section{HASIL PENELITIAN DAN PEMBAHASAN}

\section{Hasil Penelitian}

1. Deskripsi hasil Data sebelum tindakan siklus

Penelitian ini dilaksanakan dikelas $\mathrm{X}_{1}$ SMA Negeri 10 Bulukumba pada semester genap. Kelas $\mathrm{X}_{1}$ memiliki jumlah siswa 35 orang dengan rincian 13 laki-laki dan 22 perempuan.

Sebelum melaksanakan tindakan siklus, dilakukan tes kemampuan awal pada siswa kelas $\mathrm{X}_{1}$ yang akan diajarkan pada tindakan siklus. Hasil tes kemampuan awal ini, menjadi acuan peneliti dalam proses pengelompokan.

Nilai hasil tes awal di SMA Negeri 10 Bulukumba kelas $\mathrm{X}_{1}$ sebelum diadakan model pembelajaran kooperatif tipe Group Investigation.

Fakultas Keguruan dan Ilmu Pendidikan Universitas Bosowa Makassar
Tabel 1. Statistik Nilai Hasil Belajar Fisika Kelas $\mathrm{X}_{1}$ SMAN 10 BulukumbaSebelum Pelaksanaan Tindakan.

\begin{tabular}{ll}
\hline Statistik & Nilai \\
\hline Subyek & 35 \\
Skor ideal & 100 \\
Skor tertinggi & 80 \\
Skor Terendah & 25 \\
Skor Rata-rata & 42 \\
Ketuntasan Klasikal & 20 \\
\hline \multicolumn{2}{l}{ Sumber : Data setelah diolah, 2018 }
\end{tabular}

Dari tabel di atas menunjukan bahwa dari subyek 35 orang siswa dikelas $\mathrm{X}_{1}$ di SMA Negeri 10 Bulukumba nilai skor tertinggi yang didapatkan hanya 80 dari skor ideal 100, namun siswa yang mendapatkan skor terendah adalah 25 dengan skor rata-rata 42,00 persen.

Tabel 2. Ketuntasan Hasil Belajar Fisika Tes Awal Siswa Kelas $X_{1}$ SMA Negeri 10 Bulukumba

\begin{tabular}{ll}
\hline $\begin{array}{l}\text { Skor } \\
\text { Frekuensi }\end{array}$ & Frekuensi \\
Persentase (persen) & \\
\hline $\boldsymbol{x}<75$ & 28 \\
$\boldsymbol{x} \geq \mathbf{7 5}$ & 7 \\
\hline
\end{tabular}

Sumber : Data setelah diolah, 2018

Dari tabel di atas menunjukkan bahwa sebelum proses pembelajaran masih banyak siswa kelas $\mathrm{X}_{1}$ yang belum mencapai nilai standar ketuntasan yang telah ditentukaan, hal ini menjadi acuan peneliti untuk menerapkan model pembelajaran kooperatif tipe Group Investigation dalm proses pembelajaran.

\section{Deskripsi Hasil Data Tindakan Siklus I}

a. Tahap perencanaan tindakan siklus 1

Pelaksanaan tindakan siklus I berlangsung selama 3 kali pertemuan dengan lama waktu setiap pertemuan 3 jam ( 3 x 45 menit ) yang dilaksanakn pada hari Rabu 04 Maret 2018 dan dilanjutkan pada hari Rabu 11 Maret 2018. Kemudian hari Rabu 25 Maret 2018 dilaksanakan tes evaluasi siklus I 
pada pelaksanaan tindakan siklus I peneliti mengajarkan kompetensi dasar Mendeskripsikan fungsi konsumsi dan fungsi tabungan.

Sebelum dilaksanakan Tindakan siklus I atau penelitian dilaksanakan, peneliti mempersiapkan beberapa hal yang sangat dibutuhkan dalam proses penelitian, yaitu :

1) Mendiskusikan beberapa hal atau informasi penting dengan guru Fisika mengenai materi pembelajaran,situasi kelas,jadwal mengajar dan sebagainya.

2) Mempersiapkan perangkat mengajar seperti silabus, Rencana pelaksanaan pembelajaran (RPP), materi pembelajaran berupa buku Fisika kelas $\mathrm{X}$, daftar hadir siswa, dan lembar penilaian siswa.

3) Mempersiapkan format untuk penelitian seperti daftar pertanyaan untk tes awal, lembar pengamatan pelaksanaan pembelajaran untuk guru dan lembar pengamatan untuk siswa dalam proses pembelajaran.

4) Melaksanakan tes awal.

b. Tahap Pelaksanaan Tindakan siklus I

1) Kegiatan awal (pendahuluan)

Kegiatan awal atau pendahuluan dilaksanakan dengan alokasi waktu 15 menit. Rincian kegiatan sebagai berikut :

a) Beri salam kepada siswa yang hadir,

b) Peneliti melakukan absensi kepada siswa mengecek siapa siswa yang tidak hadir,

c) Memberikan sedikit motivasi kepada siswa.

d) Menyampaikan kempetensi dasar dan tujuan pembelajaran.

2) Kegiatan inti

Kegiatan inti dilaksanakan dengan alokasi waktu 105 menit. Dengan rincian kegiatan sebagai berikut :

a) Membagi 35 siswa kedalam 6 kelompok setiap kelompoknya beranggotakan 5-6 orang. b) Pemberian

materi/indikator permasalahan yang berbeda.

c) Peserta didik mencari informasi tentang materi yang dibahas pada kelompoknya.

d) Setiap kelompok mengerjakan tugas sesuai dengan materi kelompoknya dengan melakukan investigasi/ pencarian data atau berpikir dengan kemampuan berdasarkan pada pengalaman yang mereka miliki.

e) Setelah melakukan investigasi setiap kelompok mendiskusikan materi mereka masing-masing dan pendidik mengawasi jalannya diskusi.

f) Setelah melakukan diskusi kelompok, pendidik mempersilahkan setiap kelompok untuk mempresentasikan hasil diskusi kelompoknya.

g) Pendidik bersama siswa menyimpulkan materi yang telah dipelajari

h) Memberikan tugas kepada peserta didik tentang materi yang telah dipelajari.

3) Kegiatan penutup

Kegiatan penutup dilaksanakan dengan alokasi waktu 15 menit. Rincian kegiatannya sebagai berikut :

a) Pendidik memberi motivasi kepada peserta didik untuk terus meningkatkan kualitas belajar sebelum mengakhiri pembelajaran.

b) Berdoa bersama

c) Salam penutup.

Dan tes evaluasi hasil belajar peneliti lakukan ketika kegiatan pembelajaran telah berakhir atau telah sampai pada pertemuan ketiga. Tes evaluasi ini tentunya bertujuan untuk mengevaluasi siswa sampai sejauh mana materi dipahami dan melihat perubahan yang terjadi pada aspek kognitif siswa setelah model pembelajaran kooferatif tipe Group Investigation diterapkan.

c. Observasi siklus I

Sebelum dilaksanakan tindakan kelas siklus I, terlebih dahulu peneliti melakukan 
observasi awal dan pada awal pertemuan diadakan tes formatif bentuk essay sebanyak 5 butir soal. Adapun tujuan diadakan observasi awal dan tes pada akhir pembelajaran adalah untuk mengetahui dan mengukur hasil belajar pada peserta didik kelas $\mathrm{X}_{1}$ SMA Negeri 10 Bulukumba melalui penggunakan model pembelajaran kooperatif tipe Group Investigation.

Berdasarkan hasil ketuntasan belajar siswa yang didapat pada tes awal menuju tes evaluasi siklus I dapat dikatakan bahwa hasil pembelajaran meningkat. Dalam menentukan ketuntasan hasil belajar siswa, pendidik menggunakan kriteria ketutasan minimum $(\mathrm{KKM}) \geq 75$ sesuai yang telah ditetapkan sekolah. Skor 0 sampai 74 dikategorikan tidak tuntas dan 75 sampai 100 dikategorikan tuntas. Sebelum proses pembelajaran menggunakan model pembelajaran kooperatif tipe Group Investigation pendidik melakukan tes awal untuk mengetahui pemahaman siswa dan diperoleh hasil siswa yang berada pada kategori tidak tuntas sebanyak 28 orang siswa (80,00 persen) dan siswa pada kategori tuntas sebanyak 7 orang siswa (20,00persen). Pendidik melihat hasil tes awal siswa yang masih sangat jauh dari kriteri ketuntasan yang ditentukan sehingga peneliti melakukan siklus I dengan menggunakan model pembelajaran kooperatif tipe Group Investigation dalam proses pembelajaran.

Pelaksanaan observasi siklus I dimulai pada awal pembelajaran sampai pada kegiatan akhir atau penutup, guru mata pelajaran Fisika kelas $X_{1}$ SMA Negeri 10 Bulukumba. Ada beberapa komponen yang diobservasi dalam berlangsungnya proses belajar mengajar yaitu rencana pelasanaan pembelajarn, aktivitas siswa, dan aktivitas guru.

1) Data hasil observasi untuk pelaksanaan pembelajaran dikelas

Temuan penelitian tentang keberhasilan guru dalam menggunakan model pembelajaran Group Investigation dengan materi pembelajaran konsumsi dan tabungan, tujuan dilakukan observasi pada siklus 1 ini adalah untuk mengetahui sejauh mana perencanaan tindakan yang telah dibuat apakah sesuai dengan harapan, apakah berfokus pada siswa. Namun telah ditemukan masih banyak hal yang perlu diperbaiki oleh seorang peneliti antara lain sebagai berikut:

a) Dalam menyampaikan sub materi yang diberikan kepada siswa agar kiranya diperjelas maksud dari materi tersebut.

b) Pada siklus pertama ini peneliti belum bisa menguasai kelas dan memahami kondisi siswa.

2) Data hasil observasi untuk aktifitas siswa

Pada siklus I ini, keaktifan peserta didik dalam proses kegiatan belajar mengajar dapat kita lihat pada hasil observasi terhadap pelaksanaan tindakan yang dilakukan berdasarkan pengamatan peneliti pada setiap pertemuan. Adapun hasil observasi siklus I dapat dilihat pada lembar observasi pada tabel dibawah ini:

Tabel 3. Perkembangan Aktifitas Peserta Didik Kelas $\mathrm{X}_{1}$ SMA Negeri 10 Bulukumba

\begin{tabular}{clcc}
\hline No. & Komponen Yang Diamati & \multicolumn{2}{c}{ Pertemuan } \\
\cline { 3 - 4 } $\mathbf{1}$ & $\begin{array}{l}\mathbf{1} \\
\text { Peserta didik yang hadir pada } \\
\text { proses belajar mengajar }\end{array}$ & 32 & 34 \\
$\mathbf{2}$ & $\begin{array}{l}\text { Peserta didik yang } \\
\text { mengajukan pertanyaan }\end{array}$ & 5 & 9 \\
$\mathbf{3}$ & $\begin{array}{l}\text { Peserta didik yang menjawab } \\
\text { pertanyaan dari pendidik }\end{array}$ & 5 & 12 \\
$\mathbf{4}$ & $\begin{array}{l}\text { Peserta didik yang } \\
\text { memaparkan rangkumannya }\end{array}$ & 17 & 18 \\
$\mathbf{5}$ & $\begin{array}{l}\text { Peserta didik yang aktif } \\
\text { dalam kelompok }\end{array}$ & 16 & 22 \\
$\mathbf{6}$ & $\begin{array}{l}\text { Peserta didik yang aktif } \\
\text { dalam menyimpulkan }\end{array}$ & 4 & 7 \\
$\mathbf{7}$ & $\begin{array}{l}\text { Peserta didik yang } \\
\text { melakukan kegiatan lain } \\
\text { seperti ribut }\end{array}$ & 9 & 4 \\
dan bermain. & & \\
\hline
\end{tabular}

Sumber : Observasi Kegiatan Siklus I

Bahwa jumlah peserta didik yang hadir pada pertemuan pertama adalah 32 
orang dan pertemuan kedua adalah 34 orang. Adapun jumlah peserta didik yang Peserta didik yang mengajukan pertanyaan hanya 5 peserta didik yang bertanya, hal ini disebabkan karena mereka terkesan masih malu-malu untuk bertanya kepada pendidik karena belum terbiasa dengan metode pelajaran yang diterapkan dan pada pertemuan kedua sudah ada peningkatan peserta didik yang bertanya sebanyak 9 orang. Kebanyakan peserta didik yang bertanya adalah peserta didik yang lebih menonjol prestasinya di antara teman lainnya. Kemudian yang tidak bertanya dalam hal ini bukan berarti mereka sudah mengerti dengan materi yang diajarkan, tapi mereka masih belum berani mengeluarkan pendapat, takut salah sehingga enggan untuk mengemukakan pertanyaan.

Peserta didik yang menjawab pertanyaan pendidik berdasarkan materi yang diajarkan, pada pertemuan pertama hanya 5 orang dan pertemuan kedua sebanyak 12 orang. Hal ini disebabkan karena peserta didik belum percaya diri dan takut jawaban yang dikemukakan salah.

Peserta didik yang memaparkan rangkumannya pada pertemuan pertama sebanyak 17 orang, dan meningkat pada pertemuan kedua sebanyak 18 orang . Peserta didik yang aktif dalam kelompok pada pertemuan pertama sebanyak 16 orang dan meningkat pada pertemuan kedua sebanyak 22 orang Hal ini dikarenakan pada pertemuan pertama diaksanakannya model pembelajaran kooperatif tipe Group Investigation sebagian peserta didik belum memahami betul proses belajar mengajar yang diterapkan, dan ada peningkatan pada pertemuan kedua sehingga proses pembelajaran dengan model pembelajaran kooperatif tipe group Investigation secara perlahan dapat diterima oleh para peserta didik.

Adapun peserta didik yang melakukan kegiatan lain seperti ribut mengalami penurunan setiap pertemuannya yakni pada pertemuan pertama 9 orang dan pertemuan kedua 4 orang. Hal ini menandakan bahwa minat peserta didik untuk serius mengikuti kegiatan belajar mengajar mulai mengalami peningkatan.

3) Data hasil belajar siswa pada mata pelajaran Fisika

Bersarkan evaluasi terhadap hasil belajar terbukti bahwa hasil belajar siswa pada siklus I belum mencapai indicator keberhasilan secara klasikal dengan skor minimal harus 75 dan presentase ketuntasan belajar pada siklus I hanya mencapai 66,00 persen.

Tabel 4 Statistik Nilai Hasil Belajar Fisika Kelas $\mathrm{X}_{1}$ SMA Negeri 10 Bulukumba Melalui Model Pembelajaran Group Investigation pada Siklus I

\begin{tabular}{ll}
\hline \multicolumn{1}{c}{ Statistik } & Nilai Statistik \\
\hline Subyek & 35 \\
Skor ideal & 100 \\
Skor tertinggi & 90 \\
Skor Terendah & 30 \\
Skor Rata-rata & 64,22 \\
Ketuntasan Klasikal & 66.00 \\
\hline
\end{tabular}

Sumber : Data setelah diolah, 2018

Dari tabel di atas menunjukan bahwa 35 orang siswa yang mendapatkan nilai skor tertinggi yang didapatkan hanya 90 dari skor ideal 100, namun siswa yang mendapatkan skor terendah adalah 30 dengan skor rata-rata 64,22 persen dan ketuntasan minimal 66,00 persen.

Tabel 5. Distribusi Frekuensi dan Persentase Skor Tes Siklus I pada Siswa Kelas $X_{1}$ SMA Negeri 10 Bulukumba

\begin{tabular}{lllcc}
\hline No & Skor & Kategori & Frekuensi & (Persen) \\
\hline 1. & $0-59$ & kurang & 11 & 31,00 \\
2. & $60-74$ & cukup & 1 & 3,00 \\
3. & $75-89$ & baik & 21 & 60,00 \\
4. & $90-100$ & amat & 2 & 6,00 \\
& & baik & 35 & 100,00 \\
\hline
\end{tabular}

Sumber : Data setelah diolah, 2018 
Dari tabel di atas menunjukkan bahwa dari 35 siswa yang mengikuti tes siklus pertama mengalami peningkatan dari tes sebelumnya dimana siswa yang mendapatkan nilai kategori amat baik sebanyak 2 orang siswa atau 6,00 persen dan kategori baik 21 orang siswa atau 60,00 persen sedangkan yang mendapat kategori cukup hanya 1 orang siswa atau 3,00 persen dan 11 orang siswa yang mendapat kategori kurang atau 31,00 persen. Berdasarkan data tersebut masih ada sebagian kecil siswa yang belum memenuhi kreteria ketuntasan minimal itu disebabkan karena siswa tersebut tergolong siswa yang selalu melakukan kegiatan lain pada proses pembelajaran.

Tabel 6 Ketuntasan Hasil Belajar Fisika Siswa Kelas $\mathrm{X}_{1}$ SMA Negeri 10 Bulukumba pada Siklus I.

\begin{tabular}{ccc}
\hline Skor & Frekuensi & Persentase \\
\hline $\boldsymbol{x}<\mathbf{7 5}$ & 12 & 34,00 \\
$\boldsymbol{x} \geq \mathbf{7 5}$ & 23 & 66,00 \\
Total & 35 & 100,00 \\
\hline
\end{tabular}

Sumber : Data setelah diolah, 2018

Dari tabel di atas menunjukan bahwa setelah model pembelajaran kooperatif tipe Group Investigation diterapkan dalam proses pembelajaran, siswa yang mendapatkan nilai di atas kriteria ketuntasan minimal mengalami peningkatan tetapi masih ada sebagian kecil siswa yang belum memenuhi kreteria ketuntasan minimal itu disebabkan karena siswa tersebut tergolong siswa yang selalu melakukan kegiatan lain pada proses pembelajaran.

Hasil belajar untuk siklus I dapat dijadikan rekomendasi untuk lanjut ke siklus II dengan materi yang berbeda pada rencana perbaikan pembelajaran (RPP) sedangkan instrument penilaian pelaksanaan pembelajaran dan aktivitas siswa adalah tetap.

Fakultas Keguruan dan Ilmu Pendidikan Universitas Bosowa Makassar
Penerapan model pembelajaran kooperatif tipe Group Investigation dengan tujuan yaitu untuk mengetahui keinginan dan tanggapan siswa terhadap pelaksanaan metode pembelajaran atau sebagai bahan evaluasi metode pembelajaran tersebut. Keaktifan siswa dalam proses pembelajaran terlihat pada kehadiran siswa dan respon siswa pada saat proses pembelajaran berlangsung. Selain dari kehadiran siswa terlihat juga keaktifan siswa dalam memberikan pertanyaan dan menyampaikan pendapat dalam dikusi yang diberikan.

d. Tahap Refleksi siklus I

Setelah melalui tahap perencanaan, pelaksanaan, serta tahap observasi dan diakhiri dengan evaluasi hasil belajar siswa maka selanjutnya dilakukan tahap refleksi, berdasarkan hasil observasi dan evaluasi diperoleh informasi bahwa pada pelaksanaan pembelajaran berlangsung masih banyak aspek yang perlu ditingkatkan seperti memotivasi siswa, menanyakan kabar, pembagian materi, mengevaluasi kegiatan diskusi, menyimpulkan materi pelajaran, buku pendukung pembelajaran,. Dan pada aktivita ssiswa untuk kemampuaan berkomunikasi berfikir bersama kelompok juga perlu ditingkatkan, masih terdapat siswa yang melakukan aktivitas lain karena mereka telah terbiasa pada saat menggunakan metode yang digunakan sebelumnya adalah sebagai siswa pasif dan kebanyakan dari siswa yang memilih diam dibandingkan dengan mengeluarkan pendapat atau menyampaikan hasil pengamatan mereka berdasarkan materi yang dibahas, siswa terlihat masih ragu dalam menyampaikan pendapatnya.

Dari hasil tes tindakan siklus I menunjukkan persentase ketuntasan secara klasikal pada siklus I yaitu sebesar $(66,00$ persen) atau 23 dari 35 siswa berada pada kategori tuntas dan (34,00 persen) atau 12 dari 35 siswa berada pada kategori tidak tuntas, ini berarti belum tercapai ketuntasan secara klasikal sehingga memungkinkan untuk dilanjutkan pada siklus II. 


\section{Deskripsi Hasil Data Tindakan Siklus II}

a. Tahap perencanaan Tindakan siklus II

Tindakan siklus II dilaksanakan pada hari Rabu 01 April 2018 jam 07.00-09.30. Pembelajaran tindakan siklus I berlangsung selama 135 menit setiap pertemuan yang dihadiri 35 orang siswa. Adapun materi yang akan diajarkan pada siklus II adalah investasi. Sebelum pelaksaaan tindakan siklus II, peneliti mempersiapkan beberapa hal yang sangat dibutuhkan dalam proses pembelajaran, yaitu :

1) Menjadikan data yang terkumpul pada siklus I sebagai acuan untuk melaksanakan pembelajaran pada siklus II.

2) Mempersiapkan perangkat pembelajaran dan lembar observasi.

3) Guru melatih dan membekali diri lebih baik lagi, agar mampu melaksanakan proses pembelajaran lebih maksimal dari siklus I.

4) Mempelajari kembali karakteristik siswa, terutama siswa yang belum tuntas pada siklus I.

b. Tahap pelaksanaan Tindakan siklus II

Pelaksaan tindakan siklus II dilakukan sebanyak 3 kali pertemuan. Alokasi waktu dalam 1 pertemuan adalah 135 menit pelajaran yaitu 1 jam pelajaran adalah 45 menit, dimulai pukul 07.00-09.30 WITA. Dalam proses pembelajaran pada tindakan siklus 1 dibagi dalam tiga kegiatan yaitu kegiatan awal, kegiatan inti, dan kegiatan akhir.

1) Kegiatan awal (pendahuluan)

Kegiatan awal dilaksanakan dengan alokasi waktu 15 menit. Rincian kegiatan sebagai berikut :

a) beri salam kepada siswa yang hadir,

b) peneliti melakukan absensi kepada siswa mengecek siapa siswa yang tidak hadir,

c) memberikan sedikit motivasi kepada siswa. d) menyampaikan kempetensi dasar dan tujuan pembelajaran.

2) Kegiatan inti

Kegiatan inti dilaksanakan dengan alokasi waktu 105 menit. Dengan rincian kegiatan sebagai berikut :

a) Membagi 35 siswa kedalam 6 kelompok setiap kelompoknya beranggotakan 5-6 orang.

b) Pemberian materi/indikator permasalahan yang berbeda.

c) Peserta didik mencari informasi tentang materi yang dibahas pada kelompoknya.

d) Setiap kelompok mengerjakan tugas sesuai dengan materi kelompoknya dengan melakukan investigasi/ pencarian data atau berpikir dengan kemampuan berdasarkan pada pengalaman yang mereka miliki.

e) Setelah melakukan investigasi setiap kelompok mendiskusikan materi mereka masing-masing dan pendidik mengawasi jalannya diskusi.

f) Setelah melakukan diskusi kelompok, pendidik mempersilahkan setiap kelompok untuk mempresentasikan hasil diskusi kelompoknya.

g) Pendidik bersama siswa menyimpulkan materi yang telah dipelajari

h) Memberikan tugas kepada peserta didik tentang materi yang telah dipelajari.

3) Kegiatan penutup

Kegiatan penutup dilaksanakan dengan alokasi waktu 15 menit. Rincian kegiatannya sebagai berikut :

a) Pendidik memberi motivasi kepada peserta didik untuk terus meningkatkan kualitas belajar sebelum mengakhiri pembelajaran.

b) Berdoa bersama

c) Salam penutup.

Dan tes evaluasi hasil belajar peneliti lakukan ketika kegiatan pembelajaran telah berakhir atau telah sampai pada pertemuan 
ketiga. Tes evaluasi ini tentunya bertujuan untuk mengevaluasi siswa sampai sejauh mana materi dipahami dan melihat perubahan yang terjadi pada aspek kognitif siswa setelah model pembelajaran kooferatif tipe Group Investigation diterapkan.

\section{c. Tahap Observasi}

Sebelum dilaksanakan tindakan kelas siklus II, terlebih dahulu peneliti melakukan observasi siklus I. . Adapun tujuan diadakan observasi tersebut untuk mengetahui dan mengukur hasil belajar pada peserta didik kelas $X_{1}$ SMA Negeri 10 Bulukumba melalui penggunakan model pembelajaran kooperatif tipe Group Investigation.

Observasi pada siklus II dilaksanakan selama proses pembelajaran, observasi yang dimaksud adalah observasi selama pembelajaran berlangsung melalui penerapan model pembelajaran kooperatif tipe Group Investigation. Seperti yang dilakukan pada siklus sebelumnya peneliti mengobservasi tiga komponen yaitu komponen pelaksanaan pembelajaran dalam hal ini dilakukan oleh pendidik, aktivitas siswa dan hasil belajar siswa.

1) Hasil observasi untuk pelaksanaan pembelajaran

Hasil pelaksanaan pembelajaran pada siklus ini dilakukan seperti siklus sebelumnya yang dinilai oleh guru mata pelajaran Fisika ibu Risnawati SE. Penilaian pelaksanaan pembelajaran dilakukan selama proses pembelajaran siklus II berlangsung. Hasil pelaksanaan pembelajaran berada pada dengan nilai persentase 75 persen.

2) Hasil observasi aktifitas siswa

Pada siklus II ini, keaktifan peserta didik dalam proses kegiatan belajar mengajar dapat kita lihat pada hasil observasi terhadap pelaksanaan tindakan yang dilakukan berdasarkan pengamatan peneliti pada setiap pertemuan. Adapun hasil observasi siklus I dapat dilihat pada lembar observasi pada tabel dibawah ini.
Tabel 7 Perkembangan Aktifitas Peserta Didik Kelas $X_{1}$ SMA Negeri 10 Bulukumba

\begin{tabular}{|c|c|c|c|}
\hline \multirow[t]{2}{*}{ No. } & \multirow[t]{2}{*}{ Komponen Yang Diamati } & \multicolumn{2}{|c|}{ Pertemuan } \\
\hline & & 3 & 4 \\
\hline 1 & $\begin{array}{l}\text { Peserta didik yang hadir } \\
\text { pada proses belajar mengajar }\end{array}$ & 32 & 33 \\
\hline 2 & $\begin{array}{l}\text { Peserta didik yang } \\
\text { mengajukan pertanyaan }\end{array}$ & 13 & 18 \\
\hline 3 & $\begin{array}{l}\text { Peserta didik yang } \\
\text { menjawab pertanyaan dari } \\
\text { pendidik }\end{array}$ & 16 & 18 \\
\hline 4 & $\begin{array}{l}\text { Peserta didik yang } \\
\text { memaparkan rangkumannya }\end{array}$ & 18 & 18 \\
\hline 5 & $\begin{array}{l}\text { Peserta didik yang aktif } \\
\text { dalam kelompok }\end{array}$ & 28 & 30 \\
\hline 6 & $\begin{array}{l}\text { Peserta didik yang aktif } \\
\text { dalam menyimpulkan }\end{array}$ & 9 & 13 \\
\hline 7 & $\begin{array}{l}\text { Peserta didik yang } \\
\text { melakukan kegiatan lain } \\
\text { seperti ribut } \\
\text { dan bermain }\end{array}$ & 3 & 1 \\
\hline
\end{tabular}

Sumber: Observasi Kegiatan Siklus II

Hasil observasi siklus II menunjukkan bahwa terjadi peningkatan keaktifan selama proses pembelajaran berlangsung seperti yang terlihat pada Tabel 4.7. Untuk kategori yang pertama, peserta didik yang hadir pada proses belajar mengajar mengalami peningkatan yang pesat pada setiap pertemuannya yaitu pada pertemuan ke tiga 32 siswa yang hadir, dan pada pertemuan keempat 33 siswa hadir. Hal tersebut menunjukkan terjadi peningkatan motivasi dan semangat peserta didik mengikuti kegiatan pembelajaran dengan penggunaan model pembelajaran yang diterapkan selama pertemuan.

Untuk kategori kedua adalah jumlah peserta didik yang mengajukan pertanyaan pada materi yang belum dimengerti pada pertemuan ketiga adalah 13 orang, dan mengalami peningkatan pada pertemuan keempat yakni 18 orang, hal ini disebabkan peserta didik sudah lebih berani untuk membiasakan diri mengajukan pertanyaan apabila ada materi yang tidak dimengerti dengan menjauhkan fikiran untuk takut salah. Pendidik juga selalu mengingatkan kepada 
peserta didik di setiap pertemuan agar senantiasa bertanya jika ada materi yang kurang dipahami.

Kategori peserta didik yang menjawab pertanyaan yang diajukan pendidik juga mengalami peningkatan yaitu pertemuan ketiga 16 orang, pertemuan keempat 18 orang. Berbeda dengan kategori peserta didik yang yang aktif dalam kelompok mengalami peningkatan yang drastis yaitu pada pertemuan ketiga 28 orang dan pertemuan keempat 30 orang, begitu juga halnya dengan peserta didik yang aktif dalam menyimpulkan juga mengalami peningkatan yang pesat yaitu pada pertemuan ketiga 9 dan pertemuan keempat 13 orang. Hal ini disebabkan peserta didik sudah mulai menyukai sistem pembelajaran yang diterapkan sehingga motivasi belajar mereka meningkat.Kategori selanjutnya adalah peserta didik yang yang memaparkan rangkumannya pada pertemuan ketiga 18 orang kemudian pada pertemuan keempat yaitu 18 orang juga, sedangkan kategori peserta didik yang melakukan kegiatan lain seperti ribut dan bermain dari setiap pertemuan mengalami penurunan. Hal ini menunjukkan bahwa model pembelajaran kooperatif tipe GI ini dapat dikatakan berhasil membangkitkan semangat dan kerja sama antar peserta didik untuk aktif mengikuti kegiatan pembelajaran.

3) Hasil belajar siswa siklus II

Hasil observasi untuk ketuntasan belajar siswa diperoleh dari tes evaluasi siklus II yang dilakukan pada pertemuan terakhir siklus II. Ketuntasan belajar siswa terlihat sudah mencapai indikator keberhasilan secara klasikal dimana siswa yang tuntas telah mencapai 83,00 persen atau 29 siswa dan siswa yang tidak tuntas sebanyak 17,00 persen atau siswa dari 35 siswa yang mengikuti tes evaluasi.

Fakultas Keguruan dan Ilmu Pendidikan Universitas Bosowa Makassar
Tabel 8 .Statistik Nilai Hasil Belajar Fisika Kelas $X_{1}$ SMA Negeri 10 Bulukumba Melalui Model Pembelajaran Group Investigation pada Siklus II

\begin{tabular}{ll}
\hline \multicolumn{1}{c}{ Statistik } & $\begin{array}{l}\text { Nilai } \\
\text { Statistik }\end{array}$ \\
\hline Subyek & 35 \\
Skor ideal & 100 \\
Skor tertinggi & 95 \\
Skor Terendah & 50 \\
Skor Rata-rata & 76,57 \\
Ketuntasan Klasikal & 83,00 \\
\hline Sumber : Data setelah diolah, 2018
\end{tabular}

Dari tabel di atas menunjukan bahwa 35 orang siswa yang mendapatkan nilai skor tertinggi yang didapatkan hanya 95 dari skor ideal 100, namun siswa yang mendapatkan skor terendah adalah 50 dengan skor rata-rata 76,57 persen dan ketuntasan minimal 83,00 persen.

Tabel 9. Distribusi Frekuensi dan Persentase Skor Tes Siklus II pada Siswa Kelas $\mathrm{X}_{1}$ SMA Negeri 10 Bulukumba

\begin{tabular}{|c|c|c|c|c|}
\hline No & Skor & Kategori & Frekuensi & Persentase \\
\hline $\begin{array}{l}1 . \\
2 . \\
3 . \\
4 .\end{array}$ & $\begin{array}{c}0-59 \\
60-74 \\
75-89 \\
90-100\end{array}$ & $\begin{array}{l}\text { kurang } \\
\text { cukup } \\
\text { baik } \\
\text { amat baik }\end{array}$ & $\begin{array}{c}4 \\
2 \\
23 \\
6\end{array}$ & $\begin{array}{c}11,00 \\
6,00 \\
66,00 \\
17,00\end{array}$ \\
\hline & & Total & 35 & 100,00 \\
\hline
\end{tabular}

Sumber : Data setelah diolah, 2018

Dari tabel di atas menunjukkan bahwa dari 35 siswa yang mengikuti tes siklus pertama mengalami peningkatan dari tes sebelumnya dimana siswa yang mendapatkan nilai amat baik sebanyak 6 orang siswa atau 17,00 persen, kategori baik sebanyak 23 orang siswa atau 66,00 persen, namun terdapat kategori cukup sebanyak 2 orang siswa atau 6,00 persen, kategori rendah 4 orang siswa atau 11,00 persen. Namun masih ada sebagian kecil siswa yang belum memenuhi kreteria ketuntasan minimal itu disebabkan karena siswa tersebut tergolong siswa yang selalu melakukan kegiatan lain pada proses pembelajaran. 
Tabel 10. Ketuntasan Hasil Belajar Fisika Siswa Kelas $\mathrm{X}_{1}$ SMA Negeri 10 Bulukumba pada Siklus II.

\begin{tabular}{cll}
\hline Skor & Frekuensi & Persentase \\
\hline $\boldsymbol{x}<\mathbf{7 5}$ & 16 & 17,00 \\
$\boldsymbol{x} \geq \mathbf{7 5}$ & 29 & 83,00 \\
Total & 35 & 100,00 \\
\hline \multicolumn{3}{l}{ Sumber : Data setelah diolah, 2018}
\end{tabular}

Dari tabel di atas dapat dilihat bahwa hasil belejar siswa telah mencapai indikator keberhasilan yang telah ditentukan sebelumnya. Hal ini menunjukkan pada dasarnya penggunaan model pembelajaran kooperatif tipe Group Investigation memiliki potensi yang cukup baik untuk meningkatkan hasil belajar siswa, dimana dari 35 orang siswa kelas $\mathrm{X}_{1}$ yang mendapatkan nilai di atas kriteria ketuntasan minimal yaitu 83,00 persen.

\section{d. Refleksi Siklus II}

Berdasarkan lembar observasi dan analisis data pada hasil pelaksanaan siklus II, sebagian besar siswa yang dinyatakan aktif dalam menerima materi pelajaran Fisika dengan menggunakan model pembelajaran kooperatif tipe Group Investigation dengan materi investasi.hasil analisis dan peristiwa yang terjadi pada siklus ke II antara lain sebagai berikut:

1) Guru telah berusaha semaksimal munkin dalam proses pembelajaran sesuai dengan langkah yang telah ditentukan dalam rancangan model pembelajaran yaitu model pembelajaran kooferatif tipe Group Investigation .

2) Pada pelaksanaan model pembelajaran di siklus II ini menujukan bahwa siswa lebih aktif dalam proses pembelajarn

3) Peneliti sebagai guru telah mampu mengelolah kelas dan berjalannya diskusi dengan baik sehingga membuat diskusi dan pemahaman materi itu lebih hidup dari yang sebelumnya.
4) Secara keseluruhan dapat disimpulkan bahwa peserta didik telah mampu memahami materi konsumsi dan investasi itu disebabkan karena antuasias mereka dalam pembelajaran berjalan sesuai dengan apa yang diharapkan oleh peneliti.

Dengan hasil analisis dan refleksi di atas telah dibuktikan bahwa hasil belejar siswa telah mencapai indicator keberhasilan yang telah ditentukan sebelumnya. Sehingga penelian sampai pada tahapan siklus II ini telah berhasil.

\section{Pembahasan}

Jenis penelitian yang digunakan oleh peneliti dalam penelitian ini adalah penelitian tindakan kelas (Classroom Action Research) yang bertujuan untuk memperbaiki dan meningkatkan hasil belajar Fisika siswa. Jumlah siklus dalam penelitian ini terdiri dari dua siklus yang mana siklus I adalah awal penerapan model pembelajaran kooperatif tipe Group Investiation dan dilanjutkan pada siklus II untuk memperbaiki hasil yang diperoleh pada siklus I . Berikut ini merupakan kesimpulan dari setiap siklus sebagai berikut:

\section{a) Pembahasan Hasil Penelitian Siklus I}

Dalam pelaksanaan siklus I terdapat empat tahap yang dilakukan diantaranya tahap perencanaan, tahap pelaksanaan, tahap observasi dan tahap refleksi. Tahap perencanaan peneliti bersama guru mata pelajaran Fisika merencanakan apa yang harus dilakukan pada tahap pelaksanaan dan yang akan di observasi setelah pembelajaran dilakukan. Peneliti melaksanakan 2 kali pertemuan untuk proses pembelajaran dan pertemuan ketiga melakukan tes evaluasi untuk mengukur tingkat pemahaman siswa yang dinilai dari tes hasil belajar. Peneliti mendapat hasil observasi pendidik selama proses pembelajaran berlangsung seperti peneliti kurang benar dalam menayakan kabar, memotivasi, memperhatikan buku pendukung proses pembelajaran, kurang 
memberikan bimbingan kepada siswa. Pada siklus ini aktivitas peserta didik juga belum maksimal seperti aspek keaktifan, tingkat kejujuran peserta didik saat mengerjakan tes evaluasi. Peneliti melakukan tes awal siswa dengan memberikan 5 soal tentang konsumsi dan investasi yang dikerjakan siswa selama 45 menit dan diperoleh presentase hasil tes awal siswa dengan nilai rata- rata 42,00 persen, siswa yang berada pada kategori tuntas sebanyak 7 siswa (20,00 persen) dan siswa yang berada pada kategori tidak tuntas sebanyak 28 siswa $(80,00$ persen $)$, ini menunjukkan tingkat siswa masih dibawa nilai standar yang ditentukan. Peneliti mencoba melaksanakan pembelajaran dengan menggunakan model pembelajaran kooperatif tipe Group Investigation dan mendapat nilai rata- rata sebanyak 64,22 dengan kategori siswa tuntas sebanyak 23 siswa (66,00 persen) dan siswa yang belum tuntas sebanyak 12 siswa $(34,00$ persen) pada siklus I.

\section{b) Pembahasan Hasil Penelitian Siklus II}

Pelaksanaan siklus II ini merupakan hasil refleksi dari siklus I yang dilakukan selama 3 kali pertemuan, dua kali pertemuan dilakukan proses pembelajaran menggunakan model pembelajaran kooperatif tipe Group Investigation dan satu kali pertemuan terakhir digunakn untuk tes evaluasi siklus II dengan tujuan mengukur tingkat kemampuan siswa dalam memahami pelajaran dengan menggunakan model pembelajaran kooperatif tipe Group Investigation. Pendidik dengan peserta didik dalam siklus ini sudah berkolaborasi dengan baik saat proses pembelajaran berlangsung terlihat dari indikator- indikator yang akan dicapai hampir semua maksimal dan hasil tes evaluasi peserta didik juga mengalami peningkatan dari siklus sebelumnya. Siswa sudah banyak aktif dalam menyampaikan pendapat dari pokok permasalahan yang diberikan oleh guru. Siswa juga sudah banyak termotivasi untuk lebih giat belajar karena terlihat dari banyaknya siswa yang setiap pertemuan kelihatan aktif dalam proses pembelajaran yang juga ditandai dari hasil tes evaluasi. Pelaksanaan siklus II mempelajari materi kompetensi dasar Mendeskripsikan kurva permintaan investasi. Hasil belajar siswa pada siklus II mengalami peningkatan dari siklus I dimana nilai rata rata yang diperoleh 76,57 persen, siswa yang berada dikategori tuntas sebanyak 29 siswa (83,00 persen) dan siswa berada pada kategori tidak tuntas sebanyak 6 siswa $(17,00$ persen).

Berdasarkan hasil belajar siswa di temukan bahwa pada dasarnya penggunaan model pembelajaran kooperatif tipe Group Investigation memiliki potensi yang cukup baik untuk meningkatkan prestasi siswa. Hal ini di tunjukan oleh rata- rata hasil tes siswa yang di laksanakan setelah proses pembelajaran berlangsung pada setiap siklus mengalami peningkatan. Antara tes awal sebelum penerapan metode pembelajaran mengalami peningkatan namun belum menunjukkan ketercapaian indikator keberhasilan dalam penelitian ini.

Sehingga hal tersebut mengharuskan peneliti untuk melanjutkan ke siklus II dengan tetap menggunakan model pembelajaran kooperatif tipe Group Investigation Tingkat pencapaian kognitif siswa cukup optimal setiap siswa harus memperoleh minimal nilai $\geq 75$.

Perbedaan nilai hasil belajar antara siklus I dan siklus II memberikan informasi bahwa model pembelajaran kooperatif tipe Group Investigation dapat meningkatkan hasil belajar siswa. Hal ini disebabkan pada proses belajar mengajar dengan model pembelajaran kooperatif tipe Group Investigation siswa terlibat secara aktif dalam diskusi dan kemampuan dalam menjawab pertanyaan dengan menggunakan kreatifnya.

Penelitian ini sejalan dan didukung dengan penelitian yang dilakukan oleh $\mathrm{Ni}$ Putu Novi Suarin pada tahun 2013 bahwa Implementasi model pembelajaran kooperatif tipe GI (group investigation) dapat 
meningkatkan hasil dan Aktivitas belajar pkn pada siswa kelas VII 2 SMP Negeri 2 Singaraja. Penelitian terdahulu yang juga mendukung penelitian ini, dilakuakan Dinna Hidayati pada tahun 2010 dengan menggunakan Model pembelajaran kooperatif tipe Group Investigation dapat meningkatkan prestasi belajar siswa Pada mata pelajaran akuntansi Kelas xi ilmu pengetahuan sosial 4 SMA Negeri 02 Sukoharjo Tahun ajaran 2009/2010.

Dengan melihat hasil penelitian tersebut dapat disimpulkan bahwa penerapan model pembelajaran kooperatif tipe Group Investigation dapat meningkatkan hasil belajar dan motivasi siswa baik pada mata pelajaran akuntansi, pkn dan juga mata pelajaran Fisika yang dilakukan peneliti ini dan juga pada jenjang pendidikan SMP dan SMA . Peneliti ini berharap juga dapat meningkatkan hasil belajar siswa pada mata pelajaran lain sehingga kualitas pembelajaran kedepannya semakin berkualitas, dapat mencapai kompetensi dasar yang ditentutakan.

Penelitian yang telah dilakukan mulai tanggal 02 Maret s/d 30 April di kelas $\mathrm{X}_{1}$ SMA Negeri 10 Bulukumba dapat disimpulkan bahwa hipotesis tindakan diterima yaitu menggunakan model pembelajaran Kooperatif Tipe Group Investigation, maka hasil belajar peserta didik pada mata pelajaran Fisika Kelas X SMA Negeri 10 Bulukumba Meningkat. Penelitian ini sejalan dengan penelitian yang telah dilakukan oleh Ni Putu Novi Suarin pada tahun 2013 di kelas VII 2 SMP Negeri 2 Singaraja dan Dinna Hidayati pada tahun 2010. Didukung oleh teori yang ada yaitu menurut Herbert Thelen, Group Investigation (GI) melibatkan siswa sejak perencanaan, baik dalam seleksi topik maupun cara untuk mempelajarinya melalui investigasi. Metode ini menuntut siswa untuk memiliki kemampuan yang baik dalam berkomunikasi maupun dalam keterampilan proses kelompok (group process skills).

\section{KESIMPULAN}

Berdasarkan hasil analisis dan pembahasan dalam penelitian tindakan kelas terhadap penerapan pembelajaran kooperatif tipe group Investigation (GI) dalam meningkatkan hasil belajar peserta didik pada mata pelajaran Fisika standar kompetensi memahami konsumsi dan investasi di kelas $\mathrm{X}_{1}$ SMA Negeri 10 Bulukumba kabupaten Luwu serta mengacu pada rumusan masalah dalam penelitian ini yang dilaksanakan selama dua siklus, maka peneliti memperoleh kesimpulan dari hasil penelitian tindakan ini. Adapun kesimpulan yang dimaksud dalam penelitian ini adalah dengan melalui pembelajaran kooperatif tipe Group Investigation dapat meningkatkan hasil belajar peserta didik pada mata pelajaran Fisika standar kompetensi memahami konsumsi dan investasi di kelas $\mathrm{X}_{1}$ SMA Negeri 10 Bulukumba kabupaten Luwu. Hal ini dapat dilihat dari hasil observasi dan hasil tes belajar peserta didik, dimana dari hasil observasi tersebut terdapat pengembangan baik dari segi kehadiran serta keaktifan dan dari hasil tes peserta didik terdapat peningkatan dimana hasil tes siklus I peserta didik yang tuntas sebanyak 66,00 persen, sedangkan peserta didik yang tuntas pada tes siklus II sebanyak 83,00 persen

\section{DAFTAR PUSTAKA}

Ahman, Eeng. (2008). Membina Kompetensi Fisika Untuk SMA/MA Kelas X. Cetakan kedua. Bandung: Grafindo Media Pratama.

Anonim. (2013). Peraturan Pemerintah Republik Indonesia Nomor 32 Tahun 2013 Tentang Perubahan Atas Peraturan Pemerintah Nomor 19 Tahun 2005 Tentang Standar Nasional Pendidikan.

Arikunto, Suhardjino \& Supandi (2012). Penelitian Tindakan Kelas. Jakarta: Bumi Aksara. 
Aqib, Zainal. (2014). Model-model, Media dan Strategi Pembelajaran Kontekstual (Inovatif). Cetakan ketiga. Bandung: Yrama Widya.

Dimyanti \& Mudjiono. (2006). Belajar dan Pembelajaran. Jakarta: PT Rineka Cipta.

Firmansyah, A. (2012). Penerapan Model Pembelajaran Group Invertigation (GI) Dalam Meningkatkan Hasil Belajar Sosiologi Sub Pokok Bahasan Strativikasi Sosial Pada Siswa Kelas XI SMA Negeri 1 Kajuara Kabupaten Bone. Skripsi. Jurusan Pendidikan Sosiologi Universitas Muhammadiyah. Makassar.

Haling, Abdul. (2007). Belajar dan Pembelajaran. Makassar: Badan Penerbit Universitas Negeri Makassar.

Hamalik Oemar, (2011). Kurikulum dan Pembelajaran. Cetakan keduabelas. Jakarta: Bumi Aksara.

Hidayati, dinna. (2010). peningkatan prestasi belajar dengan menggunakan Model pembelajaran kooperatif tipe Group Investigation Pada mata pelajaran akuntansi Kelas xi ilmu pengetahuan sosial 4 Sma negeri 02 sukoharjo Tahun ajaran 2009/2010 (penelitian tindakan kelas). Skripsi. Universitas Sebelas Maret Surakarta.

Komalasari, Kokom. (2011). Pembelajaran Kontekstual, Konsep dan Aplikasi. Bandung: PT Refika Aditama.

Latief, Sriwahyuni. (2014). Penerapan Model Pembelajaran Kooperatif Tipe Student Teams Achievement Division (Stad) Dalam Meningkatkan Hasil Belajar Peserta Didik Pada Kompetensi Dasar Kebutuhan Dan Kelangkaan Dalam Bidang Fisika Di Kelas X.4 SMA Negeri 1 Bangkala Barat Kabupaten Jeneponto. Skripsi. Jurusan Pendidikan Fisika Universitas Negeri Makassar. Makassar.
Novi Suarini, Niputu. (2013). Implementasi Model Pembelajaran Kooperatif Tipe GI (Group Investigation) Untuk Meningkatkan Hasil dan Aktivitas Belajar PKN Pada Siswa Kelas VII 2 Smp Negeri 2 Singaraja Tahun Ajaran 2012/2013. Skripsi. Universitas pendidikan Ganesha Ingaraja.

Rusman. (2012). Model-Model Pembelajaran, Mengembangkan Profesionalisme Guru. Jakarta: PT. Raja Grafindo Persada.

Sanjaya, Wina. (2006). Strategi Pembelajaran Berorientasi Standar Proses Pendidikan. Jakarta: Kencana Prenada Media Group.

. (2012). Starategi Pembelajaran Berorientasi Standar Proses Pendidikan. Jakarta: Kencana Prenada Media Group.

Sudremi, Yuliana (2007). Pengetahuan Sosial Fisika 1 SMA/MA. Jakarta: PT Bumi Aksara.

Tampubolon, Saur. (2013). Penelitian Tindakan Kelas, Sebagai Pengembangan Profesi Pendidik dan Keilmuan. Jakarta: Erlangga..

Taniredja, Tukiran, Efi Miftah Faridli \& Sri Harmianto. (2011). Model-model Pembelajaran Inovatif. Cetakan Kedua. Bandung: Alfabeta. 